\title{
Antinociceptive and anti-inflammatory activities of ethanolic extracts of Lychnophora species
}

\author{
L.S. Guzzo ${ }^{\text {a }}$, D.A. Saúde-Guimarães ${ }^{\text {b }}$, A.C.A. Silva ${ }^{\text {a }}$, J.A. Lombardi ${ }^{\text {c }}$, \\ H.N. Guimarães ${ }^{\mathrm{d}}$, A. Grabe-Guimarães ${ }^{\mathrm{a}, *}$ \\ ${ }^{a}$ Laboratório de Farmacologia Experimental, Escola de Farmácia, Universidade Federal de Ouro Preto, Brazil \\ ${ }^{\mathrm{b}}$ Laboratório de Estudos Químicos e Biológicos de Plantas Medicinais, Escola de Farmácia, \\ Universidade Federal de Ouro Preto, Brazil \\ ${ }^{\mathrm{c}}$ Depto. de Botânica, Instituto de Biociências de Rio Claro, UNESP, Claro Rio Claro, SP, Brazil \\ ${ }^{\mathrm{d}}$ Depto de Engenharia Elétrica, Escola de Engenharia, UFMG, Belo Horizonte, MG, Brazil \\ Received 8 March 2007; received in revised form 6 November 2007; accepted 9 November 2007 \\ Available online 17 November 2007
}

\begin{abstract}
Extracts from Lychnophora species are traditionally used in Brazil as anti-inflammatory, and to treat bruise, pain and rheumatism. The ethanolic extract of aerial parts of five species of Lychnophoras and one specie of Lychnophoriopsis were examined for the antinociceptive (hot-plate and writhing tests) and anti-inflammatory (carrageenan-induced paw oedema test) activity in mice, by oral and topical routes, respectively. In the hot-plate test, the Lychnophora pinaster $(0.75 \mathrm{~g} / \mathrm{kg})$ and Lychnophora ericoides $(1.50 \mathrm{~g} / \mathrm{kg})$ extracts significantly increased the time for licking of the paws. The species Lychnophora passerina, Lychnophoriopsis candelabrum and Lychnophora pinaster, using the dose of $0.75 \mathrm{~g} / \mathrm{kg}$, and Lychnophora ericoides and Lychnophora trichocarpha in both doses evaluated $(0.75$ and $1.50 \mathrm{~g} / \mathrm{kg})$ significantly reduced the number of writhes induced by acetic acid. The administration of Lychnophora pinaster and Lychnophora trichocarpha ointments, in both concentrations evaluated (5 and 10\%, w/w), and Lychnophora passerina and Lychnophoriopsis candelabrum, in the concentration of 10\%, significantly reduced the paw oedema measured $3 \mathrm{~h}$ after carrageenan administration, suggesting, for the first time, an anti-inflammatory activity upon topical administration of these species. The present work comparatively demonstrated the antinociceptive and anti-inflammatory activities of some Brazilian Lychnophoras.
\end{abstract}

(C) 2007 Elsevier Ireland Ltd. All rights reserved.

Keywords: Lychnophoras; Anti-inflammatory activity; Carrageenan; Antinociceptive activity; Hot-plate test; Writhing test

\section{Introduction}

The genus Lychnophora (Asteraceae) comprises 34 species that are restricted to the Brazilian "cerrado" (Robinson, 1999). The aerial parts and roots of many species of Lychnophoras (Asteraceae) are widely used in Brazilian folk medicine macerated in water, ethanol or "cachaça" (sugar cane spirit), by oral or topical route, as anti-inflammatory and to treat bruise, pain and rheumatism (Cerqueira et al., 1987; Saúde et al., 1998; Lopes,

\footnotetext{
* Corresponding author at: Depto. de Farmácia, Escola de Farmácia, Universidade Federal de Ouro Preto, Rua Costa Sena, 171-Centro, Ouro Preto, CEP 35.400-000 Minas Gerais, Brazil. Tel.: +55 31355916 26; fax: +553135591628.

E-mail address: grabe@ef.ufop.br (A. Grabe-Guimarães).
}

2001; Silveira et al., 2005). Many ethnobotanical reports on the biological activities of Lychnophoras were written in the mid18th century. In Brazil, these species are popularly known as "arnica", "false arnica" or "arnica da serra" because their smell is similar to that of the Arnica montana species (Cerqueira et al., 1987). The Lychnophoras are native bushes that can be found in rupestral fields in the states of Minas Gerais, Goiás and Bahia (Cunha et al., 1995).

Among the Lychnophora species, Lychnophora ericoides (Mart.) is the most popular. Their indiscriminate picking has caused a sensitive decreasing of the Lychnophora ericoides' populations, increasing the danger of extinction of that species (IBAMA, 2005). The antimicrobial, anti-inflammatory and antinociceptive activities of Lychnophora ericoides have already been demonstrated in the literature (Cerqueira et al., 
1987; Borsato et al., 2000; Maciel, 2002; Gobbo-Neto et al., 2005; Santos et al., 2005). The dichloromethane extract of $L$. ericoides roots showed significant activity when submitted to an acetic acid-induced writhing test (Borsato et al., 2000).

The present study was conducted to verify and compare the antinociceptive and anti-inflammatory activities of ethanolic extracts of five species of Lychnophora and one species of Lychnophoriopsis.

\section{Materials and methods}

\subsection{Plant material}

Aerial parts of botanically identified Lychnophoriopsis candelabrum (Schultz-Bip.) H. Robinson, Lychnophora ericoides Mart., Lychnophora passerina (Mart.exDC.) Gardn. and Lychnophora staavioides Mart. were collected in September 2000. Lychnophora pinaster Mart. was collected in March 2003. All species were collected in the state of Minas Gerais, Brazil and were identified by the botanist, Dr. Julio Antonio Lombardi. Voucher specimens have been deposited at the Herbarium of the Instituto de Ciências Biológicas (BHCB), UFMG, Belo Horizonte, Brazil, under the reference numbers of BHCB nos. 53566, 53568, 53571, 53570 and 19520, respectively. Lychnophora trichocarpha Spreng. (Asteraceae) was collected in October 2003. A voucher specimen no. 20635 has been deposited at the Herbarium of the Instituto de Ciências Exatas e Biológicas, UFOP, Ouro Preto, MG, Brazil.

\subsection{Preparation of plant extraction}

The aerial parts of the species Lychnophora passerina, Lychnophoriopsis candelabrum, Lychnophora pinaster, Lychnophora ericoides, Lychnophora staavioides and Lychnophora trichocarpha were dried at $40{ }^{\circ} \mathrm{C}$ for 1 week and reduced to a powder. Next, $800 \mathrm{~g}$ of each species were extracted with ethanol, at room temperature, for 2 weeks. The solvent was removed under reduced pressure to afford 13.6, 5.6, 5.7, 4.6, 2.3 and $6.4 \%(\mathrm{w} / \mathrm{w})$ of crude ethanolic extracts, respectively. To use in in vivo experiments, the extracts were dissolved in DMSO (dimethylsulfoxide), Tween 80 and distilled water $(1: 1: 8)$.

\subsection{Animals}

The studies were carried out on albino mice $(30 \pm 5 \mathrm{~g})$ of either sex. The animals were housed in groups of five and maintained on a 12-h light:12-h dark cycle with a standard pellet diet and clean drinking water ad libitum. Animals receiving solutions by oral route (p.o.) were kept with no food for 8-12 h before the experiments but were allowed free access to water. The experimental protocols were approved by Ethical Committee of Universidade Federal de Ouro Preto (no. 2007/82) and are in accordance with the Guide for the Care and Use of Laboratory Animals, published by the US National Institute of Health (NIH Publication, revised in 1985).

\subsection{Antinociceptive activity}

Two different suitable methods for screening antinociceptive compounds were applied.

\subsubsection{Hot-plate test}

The hot-plate test was performed following the method of Eddy and Leimbach (1953), with modifications. Each mouse was placed singly on the hot plate at $56 \pm 1{ }^{\circ} \mathrm{C}$ and the time for licking of the paws was recorded before, and $30 \mathrm{~min}$ after, the oral administration of the six different extract solutions tested in two doses $(0.75$ or $1.50 \mathrm{~g} / \mathrm{kg}$ ), the vehicle (control group) or the standard drugs dipyrone $(200 \mathrm{mg} / \mathrm{kg}$, p.o.) or morphine $(10 \mathrm{mg} / \mathrm{kg})$ by intraperitoneal administration (i.p.). Analgesia was defined as an increase in the latency for licking of the paws, calculated as a variation $(\Delta)$ of the latency time measured before and after the administration of the solutions. Sixty seconds was taken as the cut-off time to avoid mouse tissue damage.

\subsubsection{Acetic acid-induced writhing test}

This test was performed by using the modified method described by Koster et al. (1959). The response induced by i.p. injection of acetic acid consists of a contraction of the abdominal muscle, together with a stretching of the hind limbs. Two doses of the six extracts of Lychnophoras $(0.75$ or $1.50 \mathrm{~g} / \mathrm{kg}$, p.o.), the standard drugs morphine $(10 \mathrm{mg} / \mathrm{kg}$, i.p.), dipyrone $(200 \mathrm{mg} / \mathrm{kg}$, p.o.) or indomethacin $(10 \mathrm{mg} / \mathrm{kg}$, p.o.); or the vehicle of the extracts (control group) were administered $30 \mathrm{~min}$ before a injection of acetic acid solution $(0.8 \%, \mathrm{v} / \mathrm{v})$. The total number of abdominal writhes was counted up to $30 \mathrm{~min}$ after the acetic acid administration.

\subsection{Anti-inflammatory activity}

The carrageenan-induced paw oedema test, an inflammatory model first proposed by Winter et al. (1962), was used with modifications in the present study. A volume of $0.02 \mathrm{ml}$ of $0.1 \%$ saline solution of carrageenan (Sigma, USA) was injected into the subplantar region of the mouse's right hind paw. The left paw was always submitted to a control condition and received only control treatment: the needle was introduced into the paw, but nothing was injected (Sham) or carrageenan was injected. The extracts of Lychnophoras species were applied topically in an ointment form, soon after the carrageenan injection. The ointments were prepared using solutions containing extracts $(150 \mathrm{mg} / \mathrm{ml})$ and lanoline/vaseline (3:7), resulting in concentrations of 5 and $10 \%$ (w/w), which were then topically applied by means of a spatula (0.3 g per paw). Diclofenac gel (1\%) was used as a standard anti-inflammatory drug. The base ointment (control treatment) was composed only of lanoline/vaseline. To maintain the ointment in contact with the paw until the end of the experiment, bandages were used to ensure local absorption. The full length between the dorsal and ventral faces of the paws was obtained using a caliper rule (Vonder, China) before, and $3 \mathrm{~h}$ after, the carrageenan injection (peak of oedema formation). Hind paw swelling was expressed in millimeters $(\mathrm{mm})$ and calculated as a variation $(\Delta)$. 


\subsection{Statistical analysis}

Results were presented as means \pm S.E.M. for at least 6 independent experiments. Statistical significance among groups was determined by ANOVA, followed by the Dunnet's test. $P$-values $\leq 0.05$ were taken to indicate statistical significance.

\section{Results and discussion}

This study demonstrated for the first time the comparative antinociceptive and anti-inflammatory effects of five species of Lychnophora and one species of Lychnophoriopsis, which are native species from Brazil. The species studied are currently used in folk medicine as analgesic and anti-inflammatory agents administered by oral or topical route (Cerqueira et al., 1987; Lopes, 2001).

The species L. trichocarpha, L. pinaster and L. passerina have morphologies similar to $L$. ericoides, and therefore, the users can collect them as if they were L. ericoides. L. staavioides morphology is different from that of L. ericoides; however, as it belongs to the same genus, it seemed interesting also to evaluate its antinociceptive and anti-inflammatory activities. Lychnophoriopsis candelabrum, was included in this work because, at the time this research started, it was classified as belonging to Lychnophora genus (Santos et al., 2005).

Fig. 1A shows the effect of the ethanolic extracts of Lychnophoras on the latency time for licking of the paws to thermal stimulation. The extracts of $L$. pinaster $(0.75 \mathrm{~g} / \mathrm{kg})$ and $L$. ericoides $(1.50 \mathrm{~g} / \mathrm{kg})$ induced to an antinociceptive effect, which is statistically similar to dipyrone and morphine and different from the control group. In the hot-plate test, the heat induces a cutaneous thermonociceptive effect and the stimulus integration occurs due to the stimulation of $\mathrm{C}$ non-mielinized fibers of slow conduction (Hendry et al., 1999).

Fig. 1B presents the total number of writhes induced by acetic acid, during $30 \mathrm{~min}$ of observation, begun immediately after i.p. injection. The results observed demonstrated the antinociceptive effect of L. passerina, Lychnophoriopsis candelabrum and $L$. pinaster, when using the dose of $0.75 \mathrm{~g} / \mathrm{kg}$, which is statistically similar to indomethacin. The ethanolic extracts of $L$. ericoides and L. trichocarpha in both evaluated doses $(0.75$ and $1.50 \mathrm{~g} / \mathrm{kg})$ reduced the number of writhes in a dose-dependent manner and were able to produce an antinociceptive effect in the lowest dose, similar to that induced by indomethacin, and in the highest dose, similar to that of dipyrone and morphine. The most effective extracts in producing antinociceptive activity in this test were $L$. ericoides and L. trichocarpha.

The extracts of L. passerina and Lychnophoriopsis candelabrum in the acetic acid-induced writhing test and the $L$. pinaster in both antinociceptive tests showed significant activity at the lowest dose, but not at the highest dose. Maybe the highest dose presents constituents that blunts or counteract the active constituents to induce the antinociceptive activity.

The abdominal constriction response induced by acetic acid is widely used for antinociceptive screening, which enables the detection of peripheral antinociceptive activity of compounds. Collier et al. (1968) proposed that acetic acid acts indirectly by releasing endogenous mediators that stimulate the nociceptive neurons. In mice there is a increase in the peritoneal fluid levels of PGE2 and PGF $2 \alpha$, as well as in lipooxygenase products (Deraedt et al., 1980), liberation of sympathetic nervous system mediators (Duarte et al., 1988) and the nociceptive activity
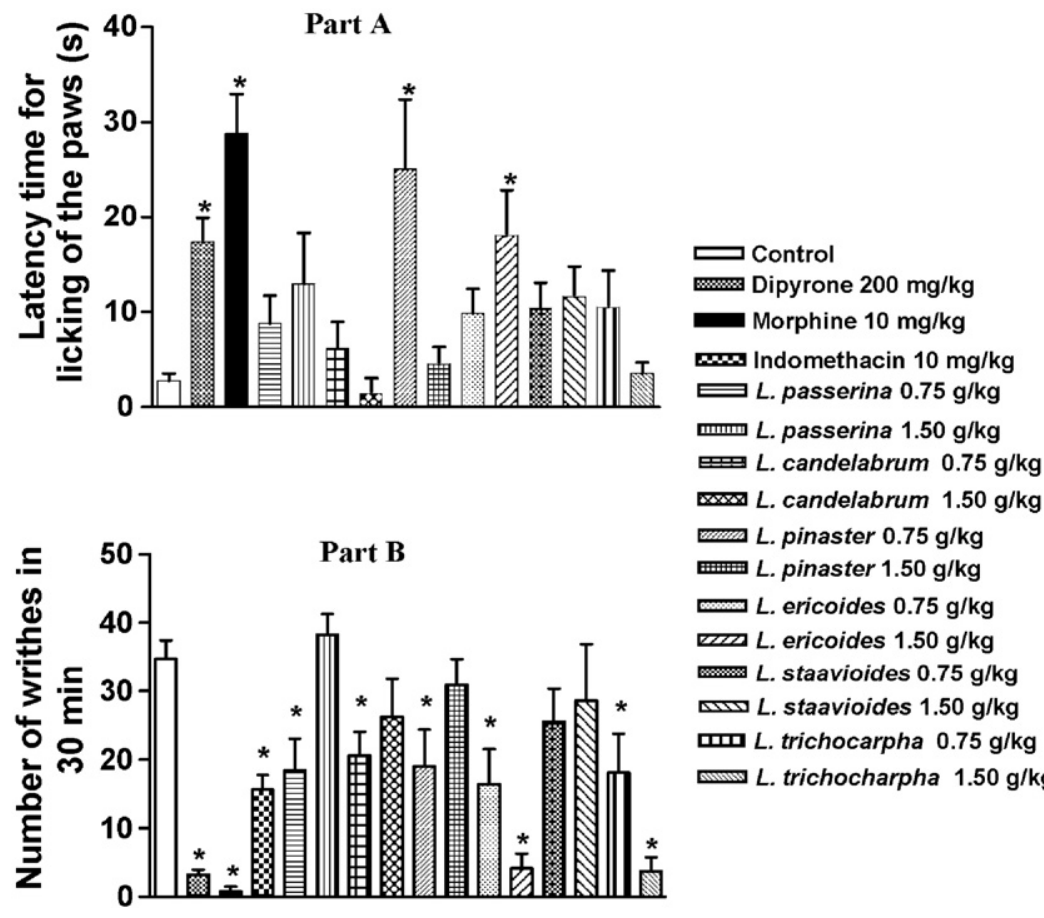

L. pinaster $0.75 \mathrm{~g} / \mathrm{kg}$

…… pinaster $1.50 \mathrm{~g} / \mathrm{kg}$

L. ericoides $0.75 \mathrm{~g} / \mathrm{kg}$

L. ericoides $1.50 \mathrm{~g} / \mathrm{kg}$

L. staavioides $0.75 \mathrm{~g} / \mathrm{kg}$

L. staavioides $1.50 \mathrm{~g} / \mathrm{kg}$

L. trichocarpha $0.75 \mathrm{~g} / \mathrm{kg}$

L. trichocharpha $1.50 \mathrm{~g} / \mathrm{kg}$

Fig. 1. Effect of ethanolic extracts of Lychnophoras in hot-plate test (A) and in total number of writhes induced by acetic acid in $30 \mathrm{~min}$ (B). Values are means \pm S.E.M. ANOVA $F_{(1.74)}=9.582$ and $F_{(1.69)}=6.660$, respectively. Dunnett's test ${ }^{*} P<0.05$ compared to the control group. 

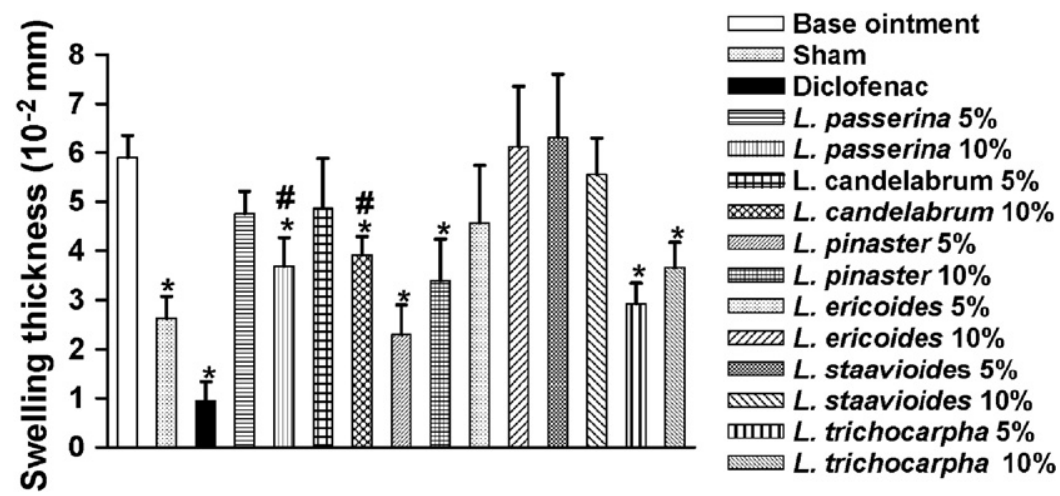

Fig. 2. Effect of ethanolic extracts of Lychnophoras in the carrageenan-induced paw oedema test. Values are means \pm S.E.M. ANOVA $F_{(1.72)}=7 \cdot 271$. Dunnett's test ${ }^{*} P<0.05$ compared to the control group. ${ }^{\#} P<0.05$ compared to the control and diclofenac groups simultaneously.

of acetic acid might be due to the release of cytokines, such as TNF- $\alpha$, interleukin- $1 \beta$, and interleukin- 8 , by resident peritoneal macrophages and mast cells (Ribeiro et al., 2000).

Using the carrageenan-induced paw oedema, the most widely used primary test for the screening of anti-inflammatory agents (Winter et al., 1962; Di Rosa, 1972), the present work showed that the topical administration of L. pinaster and L. trichocarpha ointments in both evaluated concentrations (5 and 10\%,w/w) and L. passerina and Lychnophoriopsis candelabrum (10\%, $\mathrm{w} / \mathrm{w})$, measured $3 \mathrm{~h}$ after carrageenan administration and in comparison with the control groups, significantly reduced the paw oedema, thus suggesting an anti-inflammatory activity of these ethanolic extracts (Fig. 2). Only $L$. pinaster and L. trichocarpha ointments (5 and 10\%, w/w) showed an activity that was statistically similar to diclofenac gel (standard treatment). Other Lychnophoras extracts, which present this type of activity, are less active than the standard drug (Fig. 2). Considering the topic administration of ointments containing ethanolic extracts of Lychnophoras, $0.3 \mathrm{~g}$ once time per day corresponds to 15 or $30 \mathrm{mg}$, respectively, to 5 and $10 \%$ (w/w) extract/oitment.

Carrageenan induced paw oedema is an experimental model of acute inflammation involving different phases (Vinegar et al., 1969). The early phase (1-2 h) involves the release of serotonin and histamine; kinins play a role in the middle phase (Di Rosa and Sorrentino, 1968), while prostaglandins appear to be the most important mediators in the final phase $(3-5 \mathrm{~h})$ of the postcarrageenan response (Di Rosa et al., 1971; Di Rosa, 1972). The oedema was measured $3 \mathrm{~h}$ after the application of the stimulus, considering that, at this time, the oedema had reached its highest thickness.

Considering that Lychnophora species are applied topically through infusions of ethanol (Cerqueira et al., 1987; Lopes, 2001) as an antinociceptive and/or anti-inflammatory agent, the present work, therefore, is highly relevant since it demonstrated, for the first time, the in vivo anti-inflammatory activity of the local administration of Lychnophoras extracts and indicates which species should be used for this activity.

Borsato et al. (2000) found no antinociceptive activity for the dichloromethane extract of $L$. ericoides leaves, but reported the dichloromethane extract of L. ericoides roots to possessed signif- icant antinociceptive activity. The active antinociceptive lignans, cubebin and methylcubebin were isolated from the root extract. Cubebin presented neither anti-inflammatory nor anti-pyretic activity. The caffeoilquinic acids isolated from $n$ - $\mathrm{BuOH}$ fractions from $L$. ericoides roots presented antinociceptive activity (Santos et al., 2005). Kimura et al. (1985) demonstrated that caffeoylquinic acids reduce the release of histamine from mast cells in vitro. A recent study carried out by Gobbo-Neto et al. (2005) isolated the flavonoid 6,8-di-C- $\beta$-glucosylapigenin from leaves of $L$. ericoides, showing a significant anti-inflammatory activity in the carrageenan-induced rat paw oedema. The mechanism by which the Lychnophoras extract produces antinociceptive and anti-inflammatory activities still remains unclear. The species $L$. passerina, Lychnophoriopsis candelabrum, $L$. pinaster, $L$. ericoides, $L$. staavioides and $L$. trichocarpha exhibited a high xanthine oxidase inhibitory activity and, therefore, may contain bioactive substances useful in the treatment of gout or other xanthine oxidase diseases, thus justifying the popular use of these species in rheumatisms (Ferraz Filha et al., 2006). Additionally, sesquiterpene lactones have been shown to modulate many processes that influence inflammatory reactions, as, for example, oxidative phosphorylation, platelet aggregation, as well as histamine and serotonin release (Hall et al., 1980; Schröder et al., 1990). The anti-inflammatory activity of sesquiterpene lactones has mainly been attributed to the inhibition of the transcription factor NF-kB (Lyss et al., 1997), one of the key regulators of genes involved in the immune and inflammatory response, by selectively alkylating its p65 sub-unit, most likely by reacting with cysteine residues (Lyss et al., 1998; Rüngeler et al., 1999). Although sesquiterpene lactones are known for their in vitro antiinflammatory activity, there is still no in vivo evidence for such activity.

The present study demonstrated that not every species is beneficial and that the knowledge of the pharmacological properties and their identification are essential for the rational use in folk medicine. The extract of $L$. ericoides presented a great antinociceptive activity, $L$. pinaster presented a significant antinociceptive activity (in smaller doses) as well as an expressive anti-inflammatory activity, and $L$. trichocarpha presented a significant antinociceptive activity, as demonstrated in one of the two methods used, and a great anti-inflammatory 
activity. In this manner, L. trichocarpha and L. pinaster should be used as antinociceptive and anti-inflammatory agents, while $L$. ericoides should be used as the most effective ethanolic extract to induce analgesia. In contrast, extracts of $L$. passerina and Lychnophoriopsis candelabrum presented weak antinociceptive and anti-inflammatory activities, while the extract of L. staavioides presented no activity. Hence, these three species should not be used for these medical purposes. Additionally, this is the first work that demonstrates that a simple topical formula containing an ethanolic extract of some Brazilian Lychnophoras species can indeed produce an anti-inflammatory effect. This study also presented a comparison among the defined doses of the Lychnophora species. Chemical and pharmacological studies of $L$. trichocarpha and $L$. pinaster are now in progress in our laboratories to isolate and elucidate on the structures of the active compounds responsible for these actions so as to determine their mechanisms of action.

\section{References}

Borsato, M.L., Grael, C.F., Souza, G.E., Lopes, N.P., 2000. Analgesic activity of the lignans from Lychnophora ericoides. Phytochemistry 55, 809813.

Cerqueira, M.B.S., Souza, J.T., Júnior, R.A., Peixoto, A.B.F., 1987. Ação analgésica do extrato bruto aquoso liofilizado do caule e folhas da Lychnophora ericoides Mart. (Arnica). Ciência e Cultura 39, 551-553.

Collier, H.O.J., Dinneen, J.C., Johnson, C.A., Schneider, C., 1968. The abdominal constriction response and its suppression by analgesic drugs in the mouse. British Journal of Pharmacology Chemotherapy 32, 295- 310.

Cunha, W.R., Lopes, J.L.C., Vichnewski, W., Diaz, J.G., Herz, W., 1995. Eremantholides and a guaianolide from Lychnophora rupestris. Phythochemistry 39, 387-389.

Deraedt, R., Jouquey, S., Delevallee, F., Flahaut, M., 1980. Release of prostaglandins $\mathrm{E}$ and $\mathrm{F}$ in an algogenic reaction and its inhibition. European Journal of Pharmacology 61, 17-24.

Di Rosa, M., 1972. Biological properties of carrageenan. Journal of Pharmacy and Pharmacology 24, 89-102.

Di Rosa, M., Giroud, J.P., Willoughby, D.A., 1971. Studies of the mediators of the acute inflammatory response induced in rats in different sites by carrageenan and turpentine. Journal of Pathology 104, 15-29.

Di Rosa, M., Sorrentino, L., 1968. The mechanism of the inflammatory effect of carrageenan. European Journal of Pharmacology 4, 340-342.

Duarte, I.D.G., Nakamura, M., Ferreira, S.H., 1988. Participation of the sympathetic system in acetic acid induced writhing in mice. Brazilian Journal of Medical and Biological Research 21, 341-343.

Eddy, N.B., Leimbach, D., 1953. Synthetic analgesics. II. Dithienylbutenyland dithienylbutylamines. Journal of Pharmacology and Experimental Therapeutics 107, 385-393.

Ferraz Filha, Z.S., Vitolo, I.F., Fietto, L.G., Lombardi, J.A., Saúde-Guimarães, D.A., 2006. Xanthine oxidase inibitory activity of Lychnophora species from Brazil ("Arnica”). Journal of Ethnopharmacology 107, 79-82.

Gobbo-Neto, L., Santos, M.D., Kanashiro, A., Almeida, M.C., Lucisano-Valim, Y.M., Lopes, J.L.C., Souza, G.E.P., Lopes, N.P., 2005. Evaluation of the anti-inflammatory and antioxidant activities of di-C-glucosylflavones from Lychnophora ericoides (Asteraceae). Planta Medica 71, 3-6.
Hall, I.H., Starnes, C.O., Lee, K.-H., Waddell, T.G., 1980. Mode of action of sesquiterpene lactones as anti-inflammatory agents. Journal of Pharmacological Sciences 69, 537-543.

Hendry, S.H.C., Hsiao, S.S., Bushnell, M.C., 1999. Somatic sensation. In: Zigmond, M.J., Bloom, F.E., Roberts, J.L., Squire, L.R. (Eds.), Fundamental Neuroscience. Academic Press, London, pp. 768-769.

Instituto Brasileiro do Meio Ambiente e dos Recursos Naturais Renováveis IBAMA, 2005. Espécies ameçadas de extinção no Brasil. http://www.ibama. gov.br/flora/divs/plantasextincao.pdf.

Kimura, Y., Okuda, H., Okuda, O., Hatano, T., Agata, I., Arichi, S., 1985. Studies on the activities of tannins and related compounds from medicinal plants and drugs. VI. Inhibitory effects of caffeoylquinic acids on histamine release from rat peritoneal mast cells. Chemical and Pharmaceutical Bulletin 33, 690-696.

Koster, R., Anderson, M., Beer, E.J., 1959. Acetic acid for analgesic screening. Federal Proceedings 18, 412-417.

Lopes, N.P., 2001. A essência da arnica. Fapesp Pesquisa 64, 42-44.

Lyss, G., Knorre, A., Schmidt, T.J., Pahl, H.L., Merfort, I., 1998. The antiinflammatory sesquiterpene lactone helenalin inhibits the transcription factor NF- $\kappa \mathrm{B}$ by directly targeting p65. Journal of Biological Chemistry 273, 33508-33516.

Lyss, G., Schmidt, T.J., Merfort, I., Pahl, H.L., 1997. Helenalin, an antiinflammatory sesquiterpene lactone from Arnica, selectively inhibits transcription factor NF-kB. Biological Chemistry 378, 951- 961.

Maciel, R.L., 2002. Caracterização química e avaliação da qualidade e da estabilidade de produtos fitoterápicos e homeopáticos preparados com Lychnophora pinaster Mart. e Lychnophora rupestris Semir e Leitão Filho em comparação com Arnica montana L. Fafar-UFMG. Belo Horizonte, MG. Dissertação de Mestrado em Ciências Farmacêuticas, p. 68.

Ribeiro, R.A., Vale, M.L., Thomazzi, S.M., Paschoalato, A.B.P., Poole, S., Ferreira, S.H., Cunha, F.Q., 2000. Involvement of resident macrophages and mast cells in the writhing nociceptive response induced by zymosan and acetic acid in mice. European Journal of Pharmacology 387, 111-118.

Robinson, H., 1999. Generic and sub-tribal classification of American Vernonieae. Smithsonian Contributions to Botany 89, 1-116.

Rüngeler, P., Castro, V., Mora, G., Gören, N., Vichnewski, W., Pahl, H.L., Merfort, I., Schmidt, T.J., 1999. Inhibition of transcription factor NF- $\mathrm{B}$ by sesquiterpene lactones: a proposed molecular mechanism of action. Bioorganic and Medicinal Chemistry 7, 2343-2352.

Santos, M.D., Gobbo-Neto, L., Albarella, L., Souza, G.E.P., Lopes, N.P., 2005. Analgesic activity of di-caffeoylquinic acids from roots of Lychnophora ericoides (Arnica da Serra). Journal of Ethnopharmacology 96, 545-549.

Saúde, D.A., Raslan, D.S., Souza Filho, J.D., Oliveira, A.B., 1998. Constituents from the aerial parts of Lychnophora trichocarpa. Fitoterapia LXIX, 90-91.

Schröder, H., Lösche, W., Strobach, H., Leven, W., Willuhn, G., Till, U., Schrör, K., 1990. Helenalin and 11 alpha, 13-dihydrohelenalin, two constituents from Arnica montana $\mathrm{L}$., inhibit human platelet function via thiol-dependent pathways. Thrombosis Research 57, 839-845.

Silveira, D., Wagner, H., Chiari, E., Lombardi, J.A., Assunção, A.C., Oliveira, A.B., Raslan, D.S., 2005. Biological activity of the aqueous extract of Lychnophora pinaster Mart. Brazilian Journal of Pharmacognosy 15, 294-297.

Vinegar, R., Schreiber, W., Hugo, R., 1969. Biphasic development of carrageenan oedema in rats. Journal of Pharmacology and Experimental Therapeutics $166,96-103$.

Winter, C.A., Risley, E.A., Nuss, G.W., 1962. Carrageenan-induced oedema in hind paw of the rats as an assay for anti-inflammatory drugs. In: Proceedings of the Society for Experimental Biology and Medicine, vol. 111, pp. 544-547. 